\title{
QUANTITATIVE ASPECTS OF THE KOH-E-SAFAID RANGE VEGATATION ACROSS THE ALTITUDINAL GRADIENT IN UPPER KURRAM VALLEY, PAKISTAN
}

\author{
HUSSAIN, W. $.^{*}-$ BADSHAH, L. ${ }^{2}-\mathrm{ALI}, \mathrm{A} .^{3}$ \\ ${ }^{1}$ Department of Botany, Government Post Graduate College, Parachinar, Pakistan \\ ${ }^{2}$ Phytoecology Lab., Department of Botany, University of Peshawar, 25000 Peshawar, Pakistan \\ (e-mail: badshahmasood1@gmail.com, phone: + 92-333-894-4128) \\ ${ }^{3}$ Department of Botany, Government AKL Post Graduate College, Matta, Swat, Pakistan \\ (e-mail: asghartk@gmail.com,phone: +92-333-948-5390) \\ *Corresponding author \\ e-mail: wahidhussainwahid@gmail.com; phone: + 92-300-371-2148
}

(Received $30^{\text {th }}$ Mar 2019; accepted $19^{\text {th }}$ Jun 2019)

\begin{abstract}
This phytosociological study was conducted during 2015-2018; summed up plant 7 communities of herbs, shrubs and trees at 7 monitoring sites based on elevation, habitats and physiognomic contrast. Quadrate method was employed for the data collection 5 quadrats $\left(10 \times 10 \mathrm{~m}^{2}\right)$ for trees, 10 quadrats $\left(5 \times 5 \mathrm{~m}^{2}\right)$ for shrubs and 15 quadrats $\left(1 \times 1 \mathrm{~m}^{2}\right)$ for herbs at each site. Edaphic attributes were calculated by using standard methods. Based on family importance values Pinaceae was the leading family with an FIV of (374.39) followed by Lamiaceae (350.33), Asteraceae (204.43) and Poaceae (193.67). Seven communities' viz. Berberis-Themeda-Periploca community, SeriphidiumSalvia-Thymus community and Indigofera-Quercus-Dichanthium were established at Sub-Tropical zone. While Temperate Zone comprised of Juniperus-Picea-Abies community and Quercus-Juniperus community. Abies-Picea-Rhododendron community was established at Sub-Alpine zone while JuniperusRheum-Kobresia community was established at Alpine zone. However, cluster analysis using PAST software and PC-Ord software version 5, classified the vegetation into three groups and four groups based on quantitative value respectively. Vegetation structure and its productivity were governed by soil texture and its chemical composition. The physico-chemical analysis of habitat features revealed that the soil texture was mostly sandy loam and loamy sand with $\mathrm{pH}$ ranged from 7.3 to 7.7. Afforestation programs need to be started on wasteland of the area to overcome the impacts of deforestation.
\end{abstract}

Keywords: vegetation, phytosociology, edaphic variables, maturity index, similarity index

\section{Introduction}

Study of plant communities and their classification is termed as phytosociology. Primarily phytosociology helps in understanding the multilateral relationships between plants and their environment. It deals with quantitative, qualitative and synthetic attributes of plant communities. Vegetation is an ecological quantification of plant resources (Ali et al., 2018; Timilehin et al., 2017; Badshah et al., 2016). The vegetation of an area is the reflection of its climate, soil, biodiversity, anthropogenic activities and natural resources (Ilyas et al., 2015). The vegetation structure and plant population sizes also indicate species tolerance of existing ecological attributes (Kuma and Shibru, 2015; Sher et al., 2014). The presence and the establishment of the communities reveal the plant type and surroundings condition under which they developed (Hussain et al., 2015; Zhu et al., 2015; Ahmad et al., 2006). The health of any ecosystems is dependent on plant biodiversity and thus the vegetation classification is a prerequisite for ecosystem management and biodiversity conservation. Some of the most important 
environmental factors affecting the vegetation are deforestation, erosion, trampling, overgrazing and other ecological factors. In Pakistan two-third of the area is highland type and quick changes in climate and elevation aggravates differences in plant diversity. Pakistan includes variety of land-dwelling ecosystem, with in 18 main geographic regions (Khan et al., 2016; Zoq-ul-Arfeen et al., 2015). Due to nonavailability of natural gas and electricity large population of the area depends upon forest wealth for domestic needs. Because of the intense browsing nearly all the pastures have been ruined and need restoration to be sustainable again. Phytosociologically the vegetation and forests of Koh-e-Safaid slopes are Sino-Japanese type (Hussain et al., 2019). The natural forests of Kurram cover about $8 \%$ of its area while the Parachinar Forest Department has planted about 6\% area. The land under cultivation is $35 \%$ while the rest of $47 \%$ is barren. The major forest types of the Kurram are dry tropical forest and sub alpine scrub (Hussain et al., 2013). The area is very rich in plant resources however little ecological work has been done in the region. The dry tropical vegetation covers the Southern parts while dry temperate and alpine vegetation types are found in the Northern parts of the area. In the investigated area climate is highland type and it varies at different altitude. The observed changes in the plant communities are due to season, temperature, soil type and time of sampling of the vegetation. During spring and summer many annual show dominance and cause change in the seasonal aspects. They approach each other by sharing the species and that is why $73.5 \%$ similarity occurred. However, slight changes were observed in their cover from season to season, but the predominance of annuals changed the community composition. The recorded species exhibit different dominance value due to change in habitat and altitude condition throughout the area. The study area was unexplored in terms of its phytosociology hence present study presents first report of vegetation dynamics of this part of Pakistan.

\section{Materials and methods}

\section{Study area}

The research work was carried out in Koh-e-Safaid Range Upper Kurram. Kurram is located from $33^{\circ} 20^{\prime}$ to $34^{\circ} 10^{\prime}$ north latitudes and $69^{\circ} 50^{\prime}$ to $70^{\circ} 50^{\prime}$ east longitudes. The study area covers an area of $3380 \mathrm{~km}^{2}$, including seven monitoring sites viz. SubTropical South Hills, Sub-Tropical Plain, Sub-Tropical North Hills, Temperate South Facing slopes, Temperate North Facing slopes, Sub alpine and Alpine zone (Fig. 1).

\section{Phytosociology}

Phytosociological work was carried out in 7 sites based on elevation, species structure, habitats and physiognomic contrast. Vegetation was analyzed by using 5 quadrats $\left(10 \times 10 \mathrm{~m}^{2}\right)$ for trees, 10 quadrats $\left(5 \times 5 \mathrm{~m}^{2}\right)$ for shrubs and 15 quadrats $\left(1 \times 1 \mathrm{~m}^{2}\right)$ for herbs in each site. Density, frequency and cover of each species were recorded and all the values were converted in to IV (Importance value) and FIV (Family importance value). Geographical co-ordinates of each site were noted using GPS. Different plant communities were established based on highest importance value following (Ali et al., 2018; Badshah et al., 2016; Rajendran et al., 2016; Forzieri et al., 2011). 

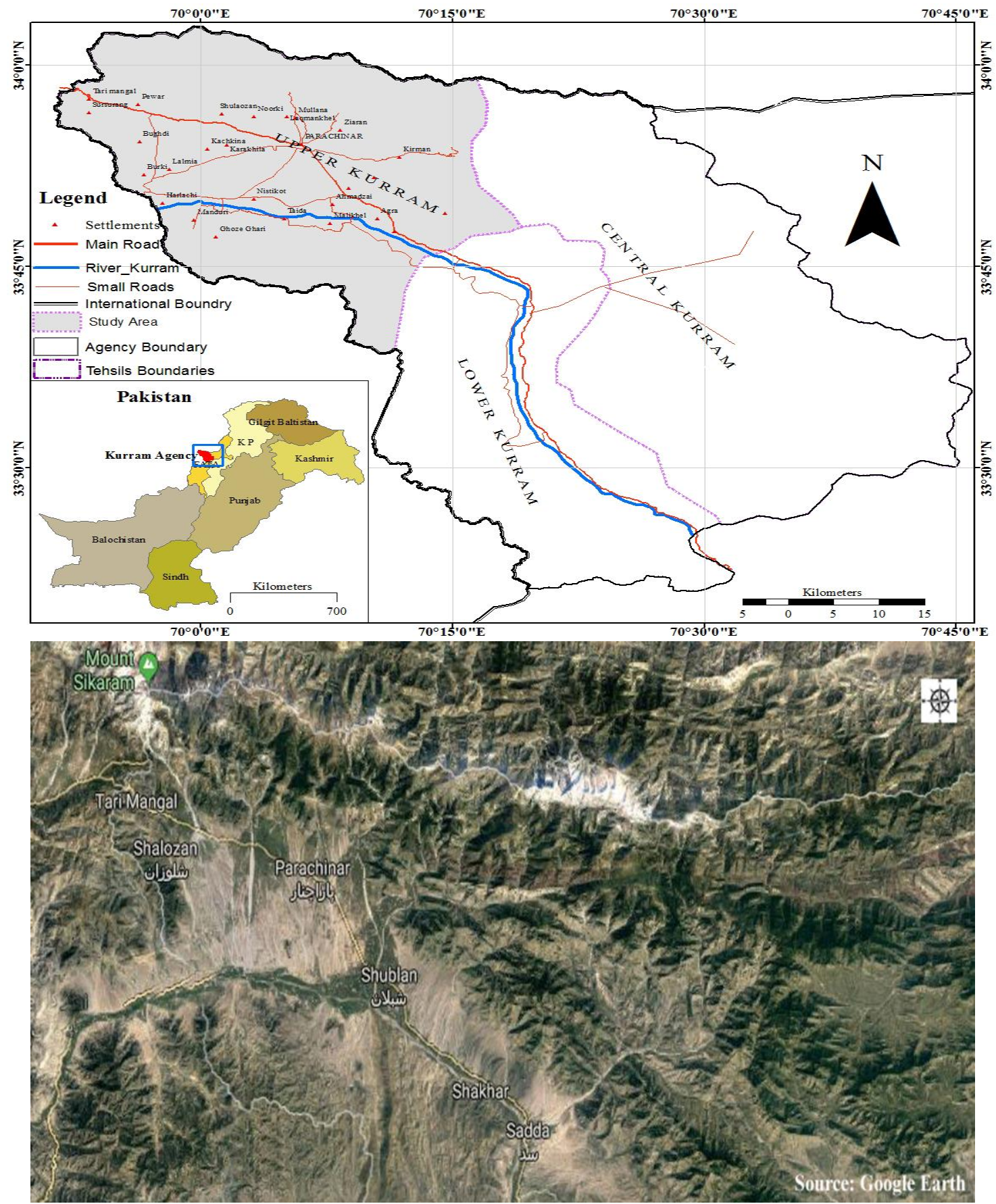

Figure 1. $\boldsymbol{a}$ Map of the study area. $\boldsymbol{b}$ Google Map of the study area of Upper Kurram Valley

\section{Data analysis}

Cluster analysis was conducted by using PAST software, Wards cluster analysis and Principal Component Analysis tools. It is a classification technique for putting similar objects into clusters. The arrangement is a hierarchical tree like structure is called a dendrogram. These clusters of sampling units may represent different biotic communities. The community classification was made by using Multivariate Statistical Package. The classification was based on structural variations among stands and 
dendrogram were made for vegetation stands of the area. A Principal Components Analysis technique was also applied to analyze spatial variations in vegetation by PCOrd software version 5 .

\section{Importance value $(I V)$}

Importance value of each species was calculated by adding all the relative values of RD, RF, RC (Ali et al., 2018; Badshah et al., 2016). The communities were named after the three leading species having the highest importance values.

$$
\mathrm{IV}=\mathrm{RD}+\mathrm{RC}+\mathrm{RF}
$$

\section{Family importance value (FIV)}

Importance value of every species in specific families was added together to obtain FIV for all the quantitatively recorded families.

\section{Maturity index}

The community maturity index of community was obtained by (Pichi-Sermolli, 1948).

$$
\text { Degree of maturity index }=\frac{\text { Frequency values of all species in a stand }}{\text { Total number of species in a stand }}
$$

\section{Similarity index}

It was applied to compare similarities between different communities. It is the number of species common to both communities. It was calculated by using Sorensen's index (Sorensen, 1948) as modified by (Motyka et al., 1950). It was applied to compare similarities between different communities.

$$
I S_{\mathrm{MO}}=\frac{2 W}{A+B} \times 100
$$

where $\mathrm{W}=$ Sum of lowest quantitative value of the species pair common to both communities, $\mathrm{A}=$ Sum of quantitative value of all species in community $\mathrm{A}, \mathrm{B}=$ Sum of quantitative value of all species in community B.

\section{Soil analysis}

Soil samples of $1 \mathrm{~kg}$ from 7 sites were collected from $0-15 \mathrm{~cm}$ depth from the selected sites of the study areas. Each of the collected samples was taken in clear polythene bags which were duly labeled and sealed on the spot. Later the soil samples were dried in an oven at 25 to $30^{\circ} \mathrm{C}$. Soil samples were screened for contaminants such as stones, plant roots and other impurities. Soil samples were grounded and passed through a $2.5 \mathrm{~mm}$ sieve (Ryan et al., 2001). Standard methods were applied to estimate soil texture (Brady, 1990; Bouyoucos, 1936), pH (Jackson, 1962), organic matter, $\mathrm{CaCO}_{3}$ (Rayan et al., 1997), electrical conductivity (Rhoades, 1996), sodium absorption ratio and sulphates (Richard, 1954). Nitrogen was determined by Kieldahl method of 
Bremner and Mulvaney (1982). Phosphorous, Potassium, Calcium and Magnesium were enumerated by Inductively Coupled Plasma Optical Emission Spectroscopy (ICPOES).

\section{Results}

Present study was conducted in Koh-e-Safaid Range Upper Kurram during 20152018. Seven monitoring sites were established viz. Sub-Tropical South Hills, SubTropical Plain, Sub-Tropical North Hills, Temperate South Facing slopes, Temperate North Facing slopes, Sub-Alpine and Alpine zone. The study area displays a unique floristic and vegetation structure. The approach of classifying vegetation into 7 different communities agrees with the work of Ali et al. (2018), Ilyas et al. (2018), Badshah et al. (2016), Siddiqui et al. (2015), Sher et al. (2014) and Ahmad et al. (2006). A total of 60 species were recorded in sampling units, of which trees were represented by 09 species, shrubs by 14 species and herbs by 37 species. Based on importance value (IV), a total of seven communities were established at seven monitoring sites. Based on family importance value Pinaceae was the leading family with an FIV of 374.39 followed by Lamiaceae (350.33), Asteraceae (204.43), Poaceae (193.67), Cupressaceae (173.97), Papilonaceae (103.93), Fagaceae (100.3), Berberidaceae (75.64), Polygonaceae (68.23) and Rosaceae with (62.55). Ranunculaceae, Saxifragaceae, Asclepiadaceae, Ericaceae, Boraginaceae, Salicaceae, Elaeagnaceae, Euphorbiaceae, Thymelaeaceae, Valerianaceae, Balsaminaceae, Oleaceae, Primulaceae, Areceaea and Scrophulariaceae had importance values ranging from 48.40 to 10.31 . The study area is divided in to four zone i.e. Sub-Tropical zone, Temperate zone, Sub-Alpine and Alpine zone based on altitude, physiognomy, soil type and variance in ecological factors. Based on IV values 7 different communities were established in four ecological zones.

\section{Sub-tropical zone}

\section{Sub-tropical south hills (site I)}

\section{Berberis-Themeda-Periploca community (BTP)}

This plant community was reported from north facing slope at southern aspects at elevation of $1525 \mathrm{~m}$. Berberis lycium was the dominant species with IV of 36.83 . Second dominant species was Themeda anathera with an IV of 34.88 forming a close association with Berberis lycium at southern lower parts of the sub-tropical zone. Periploca calophylla with an IV of 30.98 mostly dispersed among the Berberis lycium and Themeda anathera. Other prominent member of this community included Thymus linearis (29.4 IV), Aristida purpuea (27.22 IV) and Stachys parviflora (25.54 IV) and Androsace rotundifolia (11.22 IV). Common shrubs growing around this community were Daphne mucronata, Cotoneastor macrophylla, Cotoneastor microphylla, Teucrium stocksianum and Nannorrhops ritchiana. The only one tree i.e Olea ferruginea was sparsely distributed in this community (Table 2). Similar communities were also reported by Ali et al. (2018), Badshah et al. (2016), Ilyas et al. (2015) and Forzieri et al. (2011). This plant community was established at Southern aspects at an elevation of $1328 \mathrm{~m}$ up to $1525 \mathrm{~m}$. Nitrogen content of the soil was $0.401 \%$, phosphorous $810 \mu \mathrm{g} / \mathrm{g}$, potassium $8700 \mu \mathrm{g} / \mathrm{g}$, calcium $32100 \mu \mathrm{g} / \mathrm{g}$, magnesium $5100 \mu \mathrm{g} / \mathrm{g}$, sulphur $187 \mu \mathrm{g} / \mathrm{g}$, sodium $1900 \mu \mathrm{g} / \mathrm{g}$, iron $81300 \mu \mathrm{g} / \mathrm{g}$, zinc $73 \mu \mathrm{g} / \mathrm{g}$, 
manganese $731 \mu \mathrm{g} / \mathrm{g}$ and cupper $92 \mu \mathrm{g} / \mathrm{g}$. Soil $\mathrm{pH}$ at this monitoring site was 7.5 and organic matter was found to be $1.8 \%$ as shown in Tables 1 and 2.

Table 1. Soil texture and physiochemical characteristics of different sites soil of Koh-eSafaid Range Kurram

\begin{tabular}{c|c|c|c|c|c|c|c|c}
\hline S. No & Locality & & $\begin{array}{c}\text { Organic } \\
\text { matter \% }\end{array}$ & pH & EC Dsm-1 & \% Lime CaCo3 & HCO $_{3}$ & Sulphates \\
\hline 1 & Sub-Tropical South Hills & Loamy sand & 1.8 & 7.50 & 1.31 & 3.9 & 4.0 & 0.4 \\
2 & Sub-Tropical plain area & Sandy loam & 1.7 & 7.70 & 1.21 & 2.6 & 8.0 & 0.6 \\
3 & Sub-Tropical North Hills & Loamy sand & 2 & 7.66 & 0.78 & 7.3 & 4.8 & 0.5 \\
4 & Temperate North facing slope & Loamy sand & 1.9 & 7.48 & 1.06 & 2.8 & 5.0 & 4.1 \\
5 & Temperate South facing slope & Loamy sand & 1.4 & 7.33 & 0.85 & 4.5 & 3.0 & 3.5 \\
6 & Sub Alpine zone & Sandy loam & 2.4 & 6.50 & 0.68 & 7.8 & 3.5 & 1.3 \\
7 & Alpine zone & Loamy sand & 2.42 & 7.85 & 1.30 & 3.0 & 5.0 & 7.8 \\
\hline
\end{tabular}

Table 2. Soil macro and micronutrients in different sites of study area

\begin{tabular}{c|c|c|c|c|c|c|c|c|c|c|c|c|c}
\hline S. No & Locality & $\begin{array}{c}\mathbf{N}_{\mathbf{2}} \\
\mathbf{\%}\end{array}$ & $\begin{array}{c}\mathbf{P} \\
\boldsymbol{\mu g} / \mathbf{g}\end{array}$ & $\begin{array}{c}\mathbf{K} \\
\boldsymbol{\mu g} / \mathbf{g}\end{array}$ & $\begin{array}{c}\mathbf{C a} / \mathbf{g} \\
\mathbf{\mu}\end{array}$ & $\begin{array}{c}\mathbf{M g} \\
\boldsymbol{\mu g} / \mathbf{g}\end{array}$ & $\begin{array}{c}\mathbf{S} \\
\boldsymbol{\mu g} / \mathbf{g}\end{array}$ & $\begin{array}{c}\mathbf{N a} \\
\boldsymbol{\mu g} / \mathbf{g}\end{array}$ & $\begin{array}{c}\mathbf{C l} \\
\boldsymbol{\mu g} / \mathbf{g}\end{array}$ & $\begin{array}{c}\mathbf{F e} \\
\boldsymbol{\mu g} / \mathbf{g}\end{array}$ & $\begin{array}{c}\mathbf{M n} \\
\boldsymbol{\mu g} / \mathbf{g}\end{array}$ & $\begin{array}{c}\mathbf{C u} \\
\boldsymbol{\mu g} / \mathbf{g}\end{array}$ & $\begin{array}{c}\mathbf{Z n} \\
\boldsymbol{\mu g} / \mathbf{g}\end{array}$ \\
\hline 1 & Sub-Tropical South Hills & 0.401 & 810 & 8700 & 32100 & 5100 & 187 & 1900 & 2700 & 81300 & 731 & 92 & 73 \\
2 & Sub-Tropical plain area & 0.280 & 645 & 7800 & 39700 & 6300 & 263 & 2600 & 3500 & 79000 & 976 & 55 & 84 \\
3 & Sub-Tropical North Hills & 0.394 & 571 & 8300 & 36200 & 6800 & 221 & 1300 & 2500 & 81800 & 343 & 95 & 78 \\
4 & Temperate North Facing slope & 0.455 & 435 & 6580 & 39800 & 6200 & 199 & 1600 & 1500 & 15000 & 776 & 105 & 68 \\
5 & Temperate South Facing slope & 0.411 & 650 & 9900 & 39300 & 6500 & 205 & 1500 & 2000 & 83100 & 531 & 109 & 64 \\
6 & Sub-Alpine & 0.333 & 450 & 5910 & 36500 & 5900 & 175 & 1800 & 2000 & 89200 & 418 & 93 & 53 \\
7 & Alpine & 0.211 & 750 & 1090 & 39900 & 5500 & 163 & 3300 & 3500 & 73200 & 869 & 89 & 82 \\
\hline
\end{tabular}

\section{Sub-tropical plain area (site II)}

\section{Seriphidium-Salvia-Thymus community (SST)}

This herbaceous community was recorded from plains area of Sub-Tropical Zone at an elevation of $1680 \mathrm{~m}$. In this area therophytes dominated the landscape along with sparse distribution of the Elaeagnus angustifolia. Dominant species was Seriphidium kurramense with IV value of 50.50 followed by Salvia reflexa with IV of 42.10. Salvia reflexa an invasive species made thick randomly distributed patches in flooded ravines, gullies, along road side, sandy loams and on open fertile clay soils. Thymus linearis with an IV value 26.38 was found to be codominant. The other predominant species growing around this community were Parthenium hysterophorus, Artemisia scoparia, Cynodon dactylon, Conyza canadensis, Tagetis minuta and Astragalus oplites. The recorded shrubs in this community were Daphne mucronata, Indigofera heterantha, Hertia intermedia and Berberis lyceum (Table 2). Ali et al. (2018), Hussain et al. (2016), Badshah et al. (2016), Forzieri et al. (2011) and Wahab et al. (2010) have also reported similar results in their studies. Soil at this locality was sandy loam. Nitrogen content of the soil was $0.280 \%$, phosphorous $645 \mu \mathrm{g} / \mathrm{g}$, potassium $7800 \mu \mathrm{g} / \mathrm{g}$, calcium $39700 \mu \mathrm{g} / \mathrm{g}$, magnesium $6300 \mu \mathrm{g} / \mathrm{g}$, sulphur $263 \mu \mathrm{g} / \mathrm{g}$, sodium $2600 \mu \mathrm{g} / \mathrm{g}$, iron $79000 \mu \mathrm{g} / \mathrm{g}$, zinc $84 \mu \mathrm{g} / \mathrm{g}$, manganese $976 \mu \mathrm{g} / \mathrm{g}$ and cupper $55 \mu \mathrm{g} / \mathrm{g}$. Soil $\mathrm{pH}$ at this site was 7.7 and organic matter was found to be $1.7 \%$ as shown in Tables 1 and 2 . 


\section{Sub-tropical north hills (site III)}

\section{Indigofera-Quercus-Dichanthium community (IQD)}

This community was recorded from the Sub-Tropical North Hills at an elevation of $2492 \mathrm{~m}$. Thick shrub cover and comparatively thick trees of Quercus baloot near the foot hills indicated the disturbed nature of habitats which were under biotic stresses like deforestation and grazing. Dominant species was Indigofera heterantha var. gerardiana with an IV value of 42.20 followed by Quercus baloot with an IV value of 33.80. These shrubs made thick dispersed patches on mostly treeless open spaces. Codominant species was found to be Dichanthium annulatum with an IV value 29.39. Similar communities were recorded by Ali et al. (2018), Ilyas et al. (2015), Badshah et al. (2015 and Ali and Malik (2010). The rest of the species included Thymus linearis, Leptorhabdos parviflora, Medicago lupulina, Cotoneastor macrophylla, Berberis lycium, Impatiens edgeworthii and Fragaria nubicola (Table 1). Soil of the area was loamy sand. Nitrogen content of the soil was $0.394 \%$, phosphorous $571 \mu \mathrm{g} / \mathrm{g}$, potassium $8300 \mu \mathrm{g} / \mathrm{g}$, calcium $36200 \mu \mathrm{g} / \mathrm{g}$, magnesium $6800 \mu \mathrm{g} / \mathrm{g}$, sulphur $221 \mu \mathrm{g} / \mathrm{g}$ and sodium $1300 \mu \mathrm{g} / \mathrm{g}$. The microelements like iron was recorded $81800 \mu \mathrm{g} / \mathrm{g}$, zinc $78 \mu \mathrm{g} / \mathrm{g}$, manganese $343 \mu \mathrm{g} / \mathrm{g}$ and copper $95 \mu \mathrm{g} / \mathrm{g}$. Soil $\mathrm{pH}$ at this site was 7.6 and organic matter was found to be $2 \%$ as shown in Tables 1 and 2.

\section{Temperate Zone}

\section{Temperate north facing slope (site IV)}

\section{Juniperus-Picea-Abies community (JPA)}

This community was recorded on North Facing Slope of Temprate Zone dominated by Juniperus excelsa with an IV value of 65.36, almost uniformly distributed in the locality making strong association with the second dominant Picea smithiana with an IV value of 51.07. The third dominant species was Abies pendrow with an IV 25.89. The tree species were uniformly distributed while the Juniperus excelsa was found in open patches among the dominant tree species. The other associated species were Pedicularis verticilata, Aquilegia pubiflora, Phlomis bracteosa, Salex denticulate, Euphorbia wallichii, Pinus wallchiana, Valeriana jatamansi, Quercus semecarpifolia and Nepeta kurramensis (Table 1). Badshah et al. (2016), Hussain et al. (2016) and Rashid et al. (2011) also have reported similar results in their studies. This community was recorded from Temperate Zone North facing slope at an elevation of 2200 up to $2450 \mathrm{~m}$. Soil at this locality was loamy sand. Nitrogen content of the soil was $0.455 \%$, phosphorous $435 \mu \mathrm{g} / \mathrm{g}$, potassium $6580 \mu \mathrm{g} / \mathrm{g}$, calcium $39800 \mu \mathrm{g} / \mathrm{g}$, magnesium $6200 \mu \mathrm{g} / \mathrm{g}$, sulphur $199 \mu \mathrm{g} / \mathrm{g}$, sodium $1600 \mu \mathrm{g} / \mathrm{g}$, iron $15000 \mu \mathrm{g} / \mathrm{g}$, zinc $68 \mu \mathrm{g} / \mathrm{g}$, manganese $776 \mu \mathrm{g} / \mathrm{g}$ and copper $105 \mu \mathrm{g} / \mathrm{g}$. Soil $\mathrm{pH}$ at this site was 7.4 and organic matter was found to be $1.9 \%$ as shown in Tables 1 and 2.

\section{Temperate south facing slope (site V)}

5. Quercus-Juniperus community (CQJ)

Cedrus-Quercus-Juniperus community was recorded at an elevation of 2450 up to $2700 \mathrm{~m}$ on the South Facing Slopes of Temperate Zone. The area had uniformly spread Cedrus deodara forest mixed with Quercus semicarpifolia and Juniperus excelsa. The area was under tremendous biotic stress especially cutting of Pinus gerardiana, Pinus 
wallichiana, Cedrus deodara for timber wood in past and completely missing of herbage cover due to steep slopes, lacking topsoil and allelopathic effect of shading leaves of Cedrus, Pinus and Juniperus trees. In this community the dominant species was Cedrus deodara with an IV value of (66.39). Quercus semicarpifolia with an IV value of (47.71) was codominant making strong association with Juniperus excelsa with IV value of (35.29). Only few plants were recorded of Pinus gerardiana and it was abundant on PakAfghan border. The other important associated members of this community were Sophora mollis, Quercus baloot, Pinus wallichiana, Piptatherum aequiglume, Daphne mucronata, Phlomis cashmeriana and Cotoneaster macrophylla (Table 1). Our results are in line with the works of Ali et al. (2018, 2015), Bokhari et al. (2013), Badshah et al. (2015), Ilyas et al. (2015) and Forzieri et al. (2011). Soil at this locality was loamy sand. Nitrogen content of the soil was $0.411 \%$, phosphorous $810 \mu \mathrm{g} / \mathrm{g}$, potassium $8700 \mu \mathrm{g} / \mathrm{g}$, calcium $39900 \mu \mathrm{g} / \mathrm{g}$, magnesium $6500 \mu \mathrm{g} / \mathrm{g}$, sulphur $205 \mu \mathrm{g} / \mathrm{g}$, sodium $1500 \mu \mathrm{g} / \mathrm{g}$, iron 83100 $\mu \mathrm{g} / \mathrm{g}$, zinc $64 \mu \mathrm{g} / \mathrm{g}$, manganese $531 \mu \mathrm{g} / \mathrm{g}$ and copper $109 \mu \mathrm{g} / \mathrm{g}$. Soil $\mathrm{pH}$ at this site was 7.3 and organic matter was found to be $1.4 \%$ as shown in Tables 1 and 2.

\section{Sub alpine zone (site VI)}

\section{Abies-Picea-Rhododendron community (APR)}

On the North Facing Slopes Abies-Picea-Nepeta community was recorded and comparatively there was thick forest of Abies pendrow and Pice smithiana. The Rhododendron afghanicum was uniformly distributed on the open space of forest as well as inside the forest. The dominant species was Abies pendrow with an IV value 44.25. Picea smithiana with an IV value 41.56 was codominant forming a close association with Rhododendron afghanicum with an IV value of 33.36. The other associated species were Nepeta bracteosa, Pedicularis verticillata, Aquilegia pubiflora, Bistorta amplexicaulis, Cynoglossum furcatum, Cotoneaster macrophylla, Medicago lupina, Berberis vulgaris and Leptorhabdos parviflora (Table 2). Badshah et al. (2016), Hussain et al. (2016), Forzieri et al. (2011) and Mahmood et al. (2015) also have reported similar results in their studies. Soil at this locality was loamy. Nitrogen content of the soil was $0.333 \%$, phosphorous $450 \mu \mathrm{g} / \mathrm{g}$, potassium $5910 \mu \mathrm{g} / \mathrm{g}$, calcium $36500 \mu \mathrm{g} / \mathrm{g}$, magnesium $5900 \mu \mathrm{g} / \mathrm{g}$, sulphur $175 \mu \mathrm{g} / \mathrm{g}$, sodium $1800 \mu \mathrm{g} / \mathrm{g}$, iron $89200 \mu \mathrm{g} / \mathrm{g}$, zinc $64 \mu \mathrm{g} / \mathrm{g}$, manganese $418 \mu \mathrm{g} / \mathrm{g}$ and copper $93 \mu \mathrm{g} / \mathrm{g}$. Soil $\mathrm{pH}$ at this site was 7.4 and organic matter was found to be $2.4 \%$ which is typical to the podzolic soil as shown in Tables 1 and 2.

\section{Alpine zone (site VII)}

\section{Juniperus-Rheum-Kobresia community (JRK)}

This community was recorded at an elevation of above $2850 \mathrm{~m}$. This is treeless zone and only two shrubs were recorded first one was Juniper excelsa and the second was Rhododendron afghanicum and dominated by the herbs. The dominant species was Juniper excelsa with an IV value of 70.32. Rheum spiciforme with an IV value of 45.74 was codominant forming a close association with Kobresia schoenoides with an IV value 34.42. The other associative members of the community were Bergenia stracheyi, Thymus serphyllum, Morina longifolia, Phlomis bracteosa and Trifolium repens (Table 3). Badshah et al. (2016), Hussain et al. (2016) and Forzieri et al. (2011) also have reported similar results in their studies. Soil at this locality was sandy loam. 
Nitrogen content of the soil was $0.211 \%$, phosphorous $750 \mu \mathrm{g} / \mathrm{g}$, potassium $1090 \mu \mathrm{g} / \mathrm{g}$, calcium $39900 \mu \mathrm{g} / \mathrm{g}$, magnesium $5500 \mu \mathrm{g} / \mathrm{g}$, sulphur $163 \mu \mathrm{g} / \mathrm{g}$, sodium $3300 \mu \mathrm{g} / \mathrm{g}$. The micronutrients like iron was present $73200 \mu \mathrm{g} / \mathrm{g}$, zinc $82 \mu \mathrm{g} / \mathrm{g}$, manganese $869 \mu \mathrm{g} / \mathrm{g}$ and copper $89 \mu \mathrm{g} / \mathrm{g}$. Soil pH at this site was 7.85 and organic matter was found to be $2.42 \%$

Table 3. Importance value data for plant species

\begin{tabular}{|c|c|c|c|c|c|c|c|c|}
\hline S. No & Species & Site-I & Site-II & Site-III & Site-IV & Site-V & Site-VI & Site VII \\
\hline 1 & Abies pindrow (Royle ex. D. Done) Royle & 0 & 0 & 0 & 25.89 & 0 & 44.25 & 0 \\
\hline 2 & Androsace rotundifolia Hardw. & 11.22 & 0 & 0 & 0 & 0 & 0 & 0 \\
\hline 3 & Aquilegia pubiflora Wall. ex Royle & 0 & 0 & 0 & 21.3 & 12.51 & 0 & 0 \\
\hline 4 & Aristida cyanantha Steud. & 27.22 & 0 & 0 & 0 & 0 & 0 & 0 \\
\hline 5 & Artemisia scoparia Waldst. \& Kitam. & 0 & 23.6 & 26.8 & 0 & 0 & 0 & 0 \\
\hline 6 & Astragalus oplites Benth. ex R. Parker & 0 & 16.06 & 0 & 0 & 0 & 0 & 0 \\
\hline 7 & Bergenia stracheyi (Hook.f. \& Thom.) Engl. & 0 & 0 & 0 & 0 & 0 & 0 & 33.44 \\
\hline 8 & Berberis lyceum Royle & 36.83 & 8.42 & 15.3 & 0 & 0 & 20.14 & 0 \\
\hline 9 & Bistorta amplexicaulis (D.Don) Greene & 0 & 0 & 0 & 0 & 0 & 22.49 & 0 \\
\hline 10 & Cedrus deodara (Roxb. ex Lamb.) G. Don & 0 & 0 & 0 & 0 & 66.39 & 0 & 0 \\
\hline 11 & Cotoneaster macrophylla Wall. ex Lindl. & 14.37 & 0 & 16.3 & 0 & 10.87 & 22.33 & 0 \\
\hline 12 & Cotoneaster microphyllusWall. Ex Lindl. & 3.6 & 0 & 0 & 0 & 0 & 0 & 0 \\
\hline 13 & Conyza Canadensis (L.) Cronquist & 0 & 24.22 & 0 & 0 & 0 & 0 & 0 \\
\hline 14 & Cynodon dactylon (L.) Pers. & 22.81 & 0 & 0 & 0 & 0 & 0 & 0 \\
\hline 15 & Cynoglossum lanceolatum Forssk. & 0 & 0 & 0 & 0 & 0 & 19.31 & 0 \\
\hline 16 & Daphne oleoides Schreb. & 15.37 & 9.63 & 0 & 0 & 14.45 & 0 & 0 \\
\hline 17 & Dicanthum annulatum (Forssk.) Stapf. & 0 & 0 & 29.39 & 0 & 0 & 0 & 0 \\
\hline 18 & Elaeagnus angustifolia $\mathrm{L}$. & 0 & 17.8 & 0 & 0 & 0 & 0 & 0 \\
\hline 19 & Euphorbia wallichii Hook.f. & 0 & 0 & 0 & 16.71 & 0 & 0 & 0 \\
\hline 20 & Fragaria nubicola (Hook.f.) Lindl.ex Lacaita & 0 & 0 & 7.9 & 0 & 0 & 0 & 0 \\
\hline 21 & Hertia intermedia (Bioss.) Kuntze & 0 & 21.04 & 0 & 0 & 0 & 0 & 0 \\
\hline 22 & Impatiens edgeworthii Hook.f. & 0 & 0 & 14.2 & 0 & 0 & 0 & 0 \\
\hline 23 & Indigofera heterantha Brandis & 0 & 8.73 & 42.2 & 0 & 0 & 0 & 0 \\
\hline 24 & Juniper excelsa M. Bieb. & 0 & 0 & 0 & 65.36 & 35.29 & 0 & 70.32 \\
\hline 25 & Kobresia schoenoides (C. A. Mey.) Steud. & 0 & 0 & 0 & 0 & 0 & 0 & 34.42 \\
\hline 26 & Leptorhabdos parviflora (Benth)Benth. & 0 & 0 & 0 & 0 & 0 & 20.31 & 0 \\
\hline 27 & Medicago lupulina $\mathrm{L}$. & 0 & 0 & 17.4 & 0 & 0 & 10.0 & 0 \\
\hline 28 & Morina longifolia Wall. & 0 & 0 & 0 & 0 & 0 & 0 & 26.34 \\
\hline 29 & Nannorrhops ritchiana (Griff) Aitch. & 13.98 & 0 & 0 & 0 & 0 & 0 & 0 \\
\hline 30 & Nepeta bracteata Benth & 0 & 0 & 0 & 0 & 0 & 33.6 & 0 \\
\hline 31 & Nepeta kurramensis Reech.f. & 0 & 0 & 0 & 7.0 & 0 & 0 & 0 \\
\hline 32 & Olea ferruginea (Sol.) Steud. & 15.06 & 0 & 0 & 0 & 0 & 0 & 0 \\
\hline 33 & Parthenium hysterophorus $\mathrm{L}$. & 0 & 23.86 & 0 & 0 & 0 & 0 & 0 \\
\hline 34 & Periploca aphylla Decne. & 30.98 & 0 & 0 & 0 & 0 & 0 & 0 \\
\hline 35 & Perovskia atriplicifolia Benth. & 0 & 8.36 & 0 & 0 & 0 & 0 & 0 \\
\hline 36 & Pedicularis verticilata $\mathrm{L}$. & 0 & 0 & 0 & 23.18 & 0 & 28.57 & 0 \\
\hline 37 & Phlomis bracteosa Royle ex. Benth. & 0 & 0 & 0 & 20.37 & 0 & 0 & 14.24 \\
\hline 38 & Phlomis cshmeriana Royle ex Benth. & 0 & 0 & 0 & 0 & 6.62 & 0 & 0 \\
\hline 39 & Picea smithiana (Wall.) Boiss. & 0 & 0 & 0 & 51.07 & 0 & 41.56 & 0 \\
\hline 40 & Pinus gerardiana Wall.ex. D.don. & 0 & 0 & 0 & 0 & 9.81 & 0 & 0 \\
\hline 41 & Pinus wallichiana A. B. Jacks. & 0 & 0 & 0 & 21.08 & 20.18 & 0 & 0 \\
\hline 42 & Piptaatherium aequiglume Roshev. & 0 & 0 & 29.6 & 0 & 18.56 & 0 & 0 \\
\hline 43 & Quercus baloot Griff. & 0 & 0 & 33.8 & 0 & 21.93 & 0 & 0 \\
\hline 44 & Quercus semicrpypholia $\mathrm{Sm}$. & 0 & 0 & 13.79 & 0 & 47.71 & 0 & 0 \\
\hline 45 & Rhododendron afghanicum Aitch. \& Hemsl. & 0 & 0 & 0 & 0 & 0 & 29.56 & 33.87 \\
\hline 46 & Rheum speciforme Royle & 0 & 0 & 0 & 0 & 0 & 0 & 45.74 \\
\hline 47 & Salvia reflexa Hornem. & 0 & 42.1 & 0 & 0 & 0 & 0 & 0 \\
\hline 48 & Salex denticulate Anderson & 0 & 0 & 0 & 22.77 & 0 & 0 & 0 \\
\hline 49 & Stachys parviflora Benth. & 20.54 & 0 & 0 & 0 & 0 & 0 & 0 \\
\hline
\end{tabular}




\begin{tabular}{|c|c|c|c|c|c|c|c|c|}
\hline 50 & Syringga afghanica S. K. Schneid. & 0 & 0 & 25.9 & 0 & 0 & 0 & 0 \\
\hline 51 & Sericea lespedeza (Thunb.) Miq. & 14.7 & 0 & 0 & 0 & 0 & 0 & 0 \\
\hline 52 & Seriphidium kurramense (Qazilb.) Y.R. Ling & 0 & 50.5 & 0 & 0 & 0 & 0 & 0 \\
\hline 53 & Sophora mollis (Royle) Baker & 0 & 0 & 0 & 0 & 28.8 & 0 & 0 \\
\hline 54 & Tagetis minuta $\mathrm{L}$. & 0 & 16.47 & 0 & 0 & 0 & 0 & 0 \\
\hline 55 & Teucrium stocksianum Boiss. & 9.85 & 0 & 0 & 0 & 0 & 0 & 0 \\
\hline 56 & Themeda anathera (Nees ex Steud.) Hack. & 34.88 & 0 & 0 & 0 & 0 & 0 & 0 \\
\hline 57 & Trifolium repens $\mathrm{L}$. & 0 & 0 & 0 & 0 & 0 & 0 & 13.52 \\
\hline 58 & Thymus linearis var. linearis Benth. & 29.4 & 26.38 & 27.7 & 6.54 & 5.57 & 7.0 & 2.63 \\
\hline 59 & Thymus seriphylum L. & 0 & 0 & 0 & 0 & 0 & 0 & 25.45 \\
\hline 60 & Valeriana jatamansi Jones. & 0 & 0 & 0 & 15.46 & 0 & 0 & 0 \\
\hline
\end{tabular}

Site I (Sub-Tropical South Hills), Site II (Sub-Tropical Plain area), Site III (Sub-Tropical North hills), Site IV (Temperate South Facing slope), Site V (Temperate North Facing slope), Site VI (Sub-Alpine zone), Site VII (Alpine Zone)

\section{Ward's cluster analysis}

Cluster analysis was conducted by using PAST software applying Wards cluster analysis tool. These clusters are based on IV of the leading species at all monitoring sites and the combined IV of each specie.

\section{Cluster I. Juniper excela - Rhododendron afghanicum community}

This group had Juniper excela as a leading dominant with a combined IV of 171.21. This member was recorded from Site-IV (65.36 IV), Site-V (35.29 IV) and Site-VII (70.32 IV) while second dominant species was Rhododendron afghanicum with a combine IV of 63.43. This species was found at only two sites i.e. Site-VI (29.56 IV) and Site-VII (33.87 IV). Rheum speciforme, Kobresia schoenoides and Bergenia stracheyi were other important members of this group (Table 3, Fig. 2).

\section{Cluster II. Picea smithiana - Thymus linearis community}

This group had the highest species richness, dominated by Picea smithiana with a combined IV of 92.63. It was found at Site-IV (51.07 IV) and Site-VI (41.56 IV). Second dominant species was Thymus linearis with a combined IV of 105.22. It was found at Site-I (29.4 IV), Site-II (26.38 IV), Site-III (27.7 IV), Site-IV (6.54 IV), Site-V (5.57 IV), Site-VI (7.0 IV) and Site-VII (2.63 IV). Berberis lyceum (combined IV 80.69), Abies pindrow (combined IV70.14), Cotoneaster macrophyla (combined IV 53.87), Pedicularis verticilata (combined IV 51.75) and Seriphidium kurramense (combined IV 50.5) were the other prominent plant species of this cluster. This cluster also included Olea ferruginea and Pinus geraardiana but with lower IV values. Pinus gerardiana is an indicator species of Dry Temperate Zone which yields edible seeds (Table 1, Fig. 2).

\section{Cluster III. Quercus semicarpifolia - Cedrus deodara community}

Quercus semicarpifolia with 66.5 combined IV was dominant member of this group. It was found at Site-III (13.79 IV) and Site-V (52.71 IV). Second dominant species was Cedrus deodara having a combined IV of 66.39. Indigofera heterantha (50.93 IV), Quercus baloot (55.73), Artimesia scuparia (50.4 IV) and Piptatherium aequiglume (48.16 IV) were other important members of this group (Table 3, Fig. 2). 


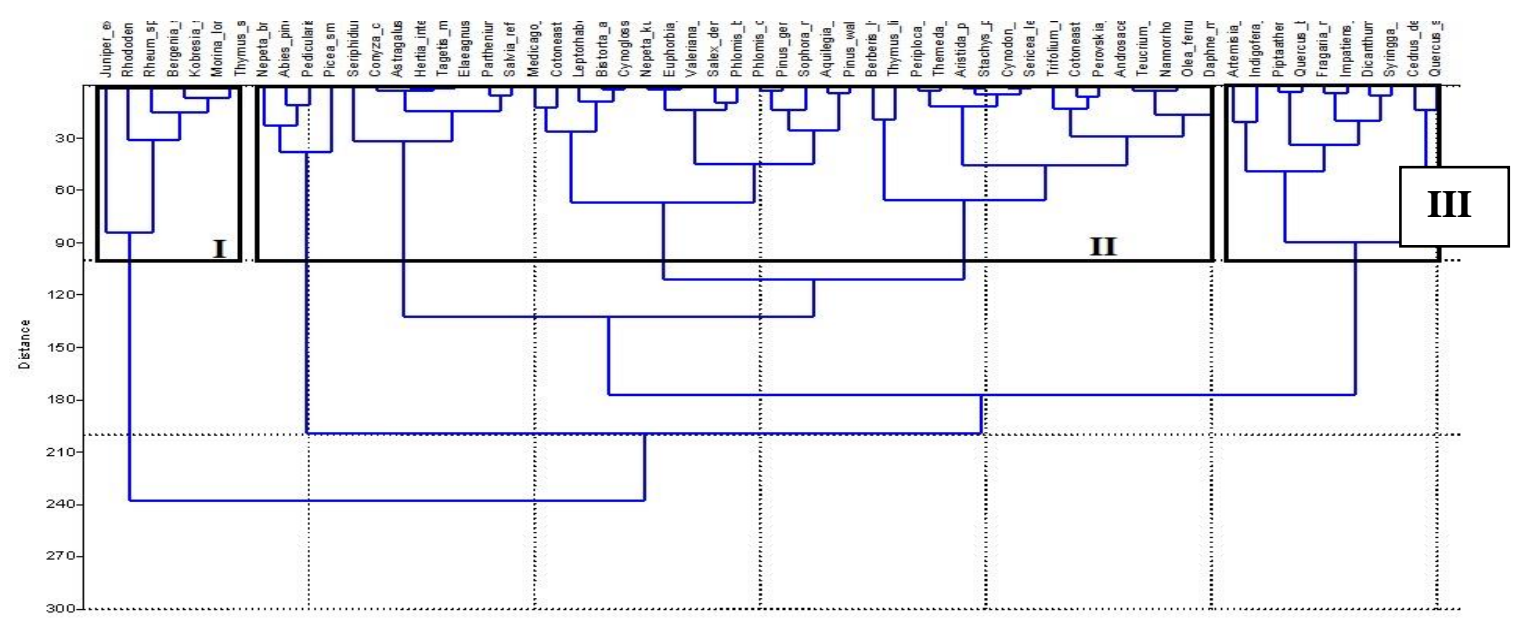

Figure 2. Cluster dendrogram analysis showing 3 associations based on IV values

\section{Principal components analysis}

Principal Components Analysis is one of the vegetation analysis techniques, which was applied by Pearson in ecology for the first time (Mesdaghi, 2001). Numerous studies have been carried out using PCA in various parts of the world to probe the connection between soil properties and vegetation (Rajendran et al., 2016, Forzieri et al., 2011, Salehi et al., 2005; Taleshi, 2004). Vegetation cover is an important variable in many earth system processes. The aim of this clustering is to analyze spatial variations in vegetation characteristics of Koh-e-Safaid Range Upper Kurram using principal component analysis. PCA was done by PC-Ord software version 5 which classified the vegetation data into 4 major components based on IVs of plant species as shown in the Figure 3.

\section{Group 1}

The dominant species in this group was Seriphidium kurramense with an IV of 50.50 , Berberis lycium with an IV of 36.83, Themeda anathera with an IV of 34.88, Quercus baloot with an IV of 33.80, Dichanthium annulatum with an IV of 33.60, Salvia reflex with an IV of 32.10, Periploca calophylla with an IV of 30.98, Thymus linearis with an IV of 29.4, Aristida purpuea with an IV of 27.22 and Leptorhabdos parviflora with an IV of 26.50. The other associative species were Stachys parviflora, Parthenium hysterophorus, Artemisia scoparia, Cynodon dactylon, Conyza canadensis, Tagetis minuta and Astragalus oplites. Soil at this site was Sandy loam. Similarly, this group had low amount of $\mathrm{N}_{2}, \mathrm{Ca}, \mathrm{Mg}, \mathrm{Cu}$, Sulphates and high values of $\mathrm{EC}, \mathrm{HCO}_{3}, \mathrm{P}$, $\mathrm{K}, \mathrm{Ca}, \mathrm{Cl}, \mathrm{Na}, \mathrm{Fe}$ and $\mathrm{Zn}$ as compare to other three groups (Fig. 3).

\section{Group 2}

In this group Indigofera gerardiana with an IV value of 52.20 followed by Quercus baloot with an IV of 33.80 and Dichanthium annulatum with an IV of 33.60 were dominant species. The rest of the associative species were Thymus linearis, Leptorhabdos parviflora, Medicago lupulina, Cotoneastor macrophylla, Berberis lycium, Impatiens edgeworthii and Fragaria nubicola. The soil characteristic in group 2 
Sub-Tropical North Hills was loamy sand, with low EC, $\mathrm{N}_{2}, \mathrm{P}, \mathrm{Ca}, \mathrm{Na}, \mathrm{Mn}, \mathrm{Cu}, \mathrm{Zn}$, and Sulphates while $\mathrm{CacO}_{3}, \mathrm{HCO}_{3}, \mathrm{~K}, \mathrm{Mg}, \mathrm{S}, \mathrm{Cl}$ and $\mathrm{Fe}$ contents (Fig. 3).

\section{Group 3}

In this group Cedrus deodara with an IV of 66.39 was dominant species followed by Quercus semicarpifolia with an IV of 52.71 making strong association with Juniperus excelsa with IV of 38.29. The other important associated members of this group were Sophora mollis, Quercus baloot, Pinus wallichiana, Piptatherum aequiglume, Daphne mucronata, Phlomis cashmeriana, Cotoneaster macrophylla and Pinus gerardiana. Studies on edaphic variables of this group showed that the soil EC was lower than the soil of other groups. Similarly, the amount of $\mathrm{HCO}_{3}, \mathrm{P}, \mathrm{Mg}, \mathrm{Cl}, \mathrm{Cu}, \mathrm{Na}, \mathrm{Mn}$ and $\mathrm{Zn}$ contents were low while N, K, S, Ca, Cu, Fe and Sulphates were comparatively (Fig. 3).

\section{Group 4}

This group was most diverse in terms of species richness having Juniperus excelsa as dominant species with an IV of 70.32, Picea smithiana with an IV of 51.07, Rheum speciforme with an IV of 45.74, Abies pindrow with an IV of 44.25, Kobresia schoenoides with an IV of 34.42, Rhododendron afghanicum with an IV of 33.36, Nepeta bracteosa with an IV of 29.56 and Pedicularis verticillata with an IV of 28.57. The other associated members were Thymus seriphylum, Morina longifolia, Aquilegia pubiflora, Bistorta amplexicaulis, Aquilegia pubiflora, Phlomis bracteosa, Cynoglossum furcatum, Salex denticulate, Cotoneaster macrophylla, Euphorbia wallichii, Pinus wallchiana, Medicago lupina, Valeriana jatamansi, Berberis vulgaris, Phlomis bracteosa and Leptorhabdos parviflora. The characteristics of the soil associative with this group show that the soil EC was lower than the soil of other groups. Similarly, this group had low amount of $\mathrm{N}, \mathrm{P}, \mathrm{Mg}, \mathrm{S}, \mathrm{Cl}, \mathrm{Cu}$ and $\mathrm{Zn}$ and high values of $\mathrm{HCO}_{3} \mathrm{~K}, \mathrm{Ca}, \mathrm{Na}, \mathrm{Fe}$ and Sulphates as compare to groups (Fig. 3).

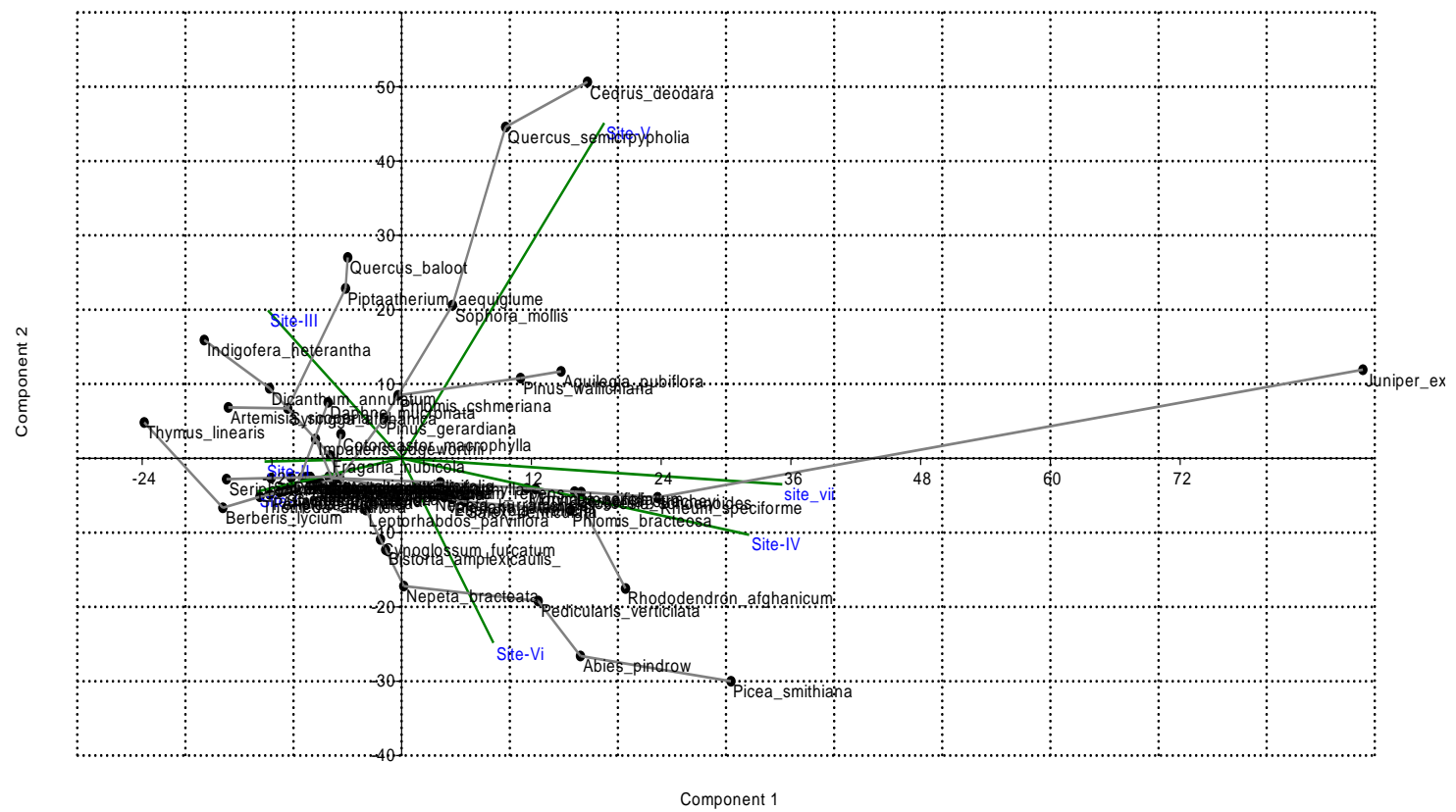

Figure 3. Principal components analysis showing 4 associations based on IV values 


\section{Maturity index}

During the current study the species maturity index ranged from 74.16 to 48.88 . The high maturity index was recorded (74.16) both at sub-tropical north zone and temperate south facing zone followed by (72.13) at sub-tropical south zone, (67.49) at sub alpine zone, (64.89) at alpine zone, (64.84) at temperate north facing zone and (48.88) at subtropical plain zone (Table 4).

Table 4. Maturity index

\begin{tabular}{c|c|c}
\hline Sites & Communities & Maturity index \\
\hline Sub-tropical south hills & Berberis-Themeda-Periploca & 72.13 \\
Sub-tropical plain area & Seriphidium-Salvia-Thymus & 48.88 \\
Sub-tropical north hills & Indigofera-Quercus-Dichanthium & 74.16 \\
Temperate north facing slope & Juniperus-Picea-Abies & 74.16 \\
Temperate south facing slope & Cedrus-Quercus-Juniperus & 64.84 \\
Sub-alpine zone & Abies-Picea-Rhododendron & 67.49 \\
Alpine zone & Juniperus-Rheum-Kobresia & 64.89 \\
\hline
\end{tabular}

\section{Index of similarity}

A similarity index does not consider the relative abundance of species. It is helpful when key concern lies in the absence or presence of species. Degree of similarity between two plant communities allows combining them into an association (Badshah et al., 2010). According to the Motyka's index of similarity (Motyka et al., 1950), Berberis-Themeda-Periploca community of Sub-Tropical South Hills was found to be $14.90 \%$ like Seriphedium-Salvia-Thymus community of Sub-Tropical plain area. The similarity between Berberis-Themeda-Periploca community of Sub-Tropical South Hills and Indigofera-Quercus-Dichanthium community of Sub-Tropical North Hills was observed $15.81 \%$. The current analysis shows that similarity between BerberisThemeda-Periploca community of Sub-Tropical South Hills and that of JuniperusPicea-Abies community of Temperate Zone North facing slope was $2.18 \%$. The Berberis-Themeda-Periploca community of Sub-Tropical South Hills and CedrusQuercus-Juniperus community of Temperate Zone South facing slope showed $8.16 \%$ similarity. The similarity between Berberis-Themeda-Periploca community SubTropical South Hills and Abies-Picea-Rhododendron of Sub-Alpine Zone was recorded $10.53 \%$. The similarity between Berberis-Themeda-Periploca community of SubTropical South Hills and Juniperus-Rheum-Kobresia of Alpine zone was $0.87 \%$. The community of Sub-Tropical plain i.e. Seriphedium-Salvia-Thymus was $22.48 \%$ similar to Indigofera-Quercus-Dichanthium community of Sub-Tropical North hills. The Seriphedium-Salvia-Thymus community of Sub-Tropical plain was found $2.19 \%$ similar to Juniperus-Picea-Abies community of Temperate North Facing slope. The Seriphedium-Salvia-Thymus community of Sub-Tropical plain was similar to CedrusQuercus-Juniperus community of Temperate South Facing slope i.e. 5.10\%. The Seriphedium-Salvia-Thymus community of Sub-Tropical plain was found 5.17\% similar to Abies-Picea-Rhododendron community of Sub-Alpine Zone. The SeriphediumSalvia-Thymus community of Sub-Tropical plain was observed $0.88 \%$ similar to the Juniperus-Rheum-Kobresia community of Alpine Zone. The Indigofera-QuercusDichanthium community of Sub-Tropical North Hills was $2.18 \%$ like Juniperus-Picea- 
Abies community of Temperate Zone North Facing slope and $19.0 \%$ similar to CedrusQuercus-Juniperus Temperate South Facing slope. The Indigofera-QuercusDichanthium community of Sub-Tropical North Hills showed $16.22 \%$ similarity with Abies-Picea-Rhododendron community of Sub-Alpine Zone. Similarity between Indigofera-Quercus-Dichanthium community Sub-Tropical North Hills and JuniperusRheum-Kobresia community of Alpine Zone was 0.87\%. The Juniperus-Picea-Abies community of Temperate North Facing slope showed $24.61 \%$ similar to CedrusQuercus-Juniperus community at Temperate South Facing slope. The Juniperus-PiceaAbies community of Temperate North Facing slope was found $32.49 \%$ similar to AbiesPicea-Rhododendron community at Sub-Alpine Zone. The Juniperus-Picea-Abies community of Temperate North Facing slope and Juniperus-Rheum-Kobresia community at Alpine Zone showed $27.45 \%$ similarity. A 5.50\% similarity was recorded between Cedrus-Quercus-Juniperus community of Temperate South Facing slope and Abies-Picea-Rhododendron community of Sub-Alpine Zone. Comparison of CedrusQuercus-Juniperus community of Temperate South Facing slope and Juniperus-RheumKobresia community at Alpine Zone showed $12.68 \%$ similarity while Abies-PiceaRhododendron community of Sub-Alpine Zone and Juniperus-Rheum-Kobresia community of Alpine Zone community showed 10.74\% similarity (Table 5). The current results agree with those of Ilyas et al. (2018), Khan et al. (2016), Urooj et al. (2016), Mehmood et al. (2015), Rashid et al. (2011), Wahab et al. (2010), Ali and Malik (2010) and Mesdaghi (2001), who reported similarities among the plant communities is due to soil properties, ecological and biotic factors.

Table 5. Similarity index for seven different communities

\begin{tabular}{c|c|c|c|c|c|c|c}
\hline & BTP & SST & IQD & JPA & CQJ & APR & JRK \\
\hline BTP & $\mathrm{X}$ & $\mathrm{X}$ & $\mathrm{X}$ & $\mathrm{X}$ & $\mathrm{X}$ & $\mathrm{X}$ & $\mathrm{X}$ \\
SST & 14.90 & $\mathrm{X}$ & $\mathrm{X}$ & $\mathrm{X}$ & $\mathrm{X}$ & $\mathrm{X}$ & $\mathrm{X}$ \\
$\mathrm{IQD}$ & 15.81 & 22.48 & $\mathrm{X}$ & $\mathrm{X}$ & $\mathrm{X}$ & $\mathrm{X}$ & $\mathrm{X}$ \\
JPA & 2.18 & 2.19 & 2.18 & $\mathrm{X}$ & $\mathrm{X}$ & $\mathrm{X}$ & $\mathrm{X}$ \\
CQJ & 8.16 & 5.10 & 19.0 & 24.61 & $\mathrm{X}$ & $\mathrm{X}$ & $\mathrm{X}$ \\
APR & 10.53 & 5.17 & 16.22 & 32.49 & 5.50 & $\mathrm{X}$ & $\mathrm{X}$ \\
JRK & 0.87 & 0.88 & 0.87 & 27.45 & 12.68 & 10.74 & $\mathrm{X}$ \\
\hline
\end{tabular}

BTP-Berberis-Themeda-Periploca community, SST-Seriphidium-Salvia-Thymus community, IQDIndigofera-Quercus-Dichanthium community, JPA-Juniperus-Picea-Abies community, CQJ- CedrusQuercus-Juniperus community, APR-Abies-Picea-Rhododendron community, JRK-Juniperus-RheumKobresia community

\section{Discussion}

During the current study the vegetation of the area was classified into seven communities which is in line with the works of Ali et al. (2018, 2015), Badshah et al. (2016) Ilyas et al. (2015), Saurav and Das (2014), Sharma et al. (2014) Saglam (2013), Ahmad et al. (2010), Digiovinazzo et al. (2010), Hussain et al. (2010), Mohler et al. (2006) Munhoz et al. (2006) and Padalia et al. (2004). The research area is under tremendous anthropogenic stress, due to which the vegetation showed clumping rather than a uniform pattern of distribution due to excessive deforestation in the area. Scanty trees and comparatively thick shrub cover at Sub-Tropical North foothills and Temperate zone indicated the disturbed nature of habitat. Due to rapid population and 
construction of buildings is the chief reason behind the species loss in this locality. Impacts of soil erosion were more visible at Site I, Site II, III, IV and Site-VII where eroded soils had herbaceous members such as Plantago major, Rumex hastatus, Thymus linearis and Verbascum thapsus which are indicator species of eroded soils. Indigofera gerardiana, cotoneaster microphyllus were observed to form randomly dispersed thick patches at site III, IV, Juniperus communis, Rhododendron afghanicum and Salex denticulate monitoring site V and VI (Fig. 4).

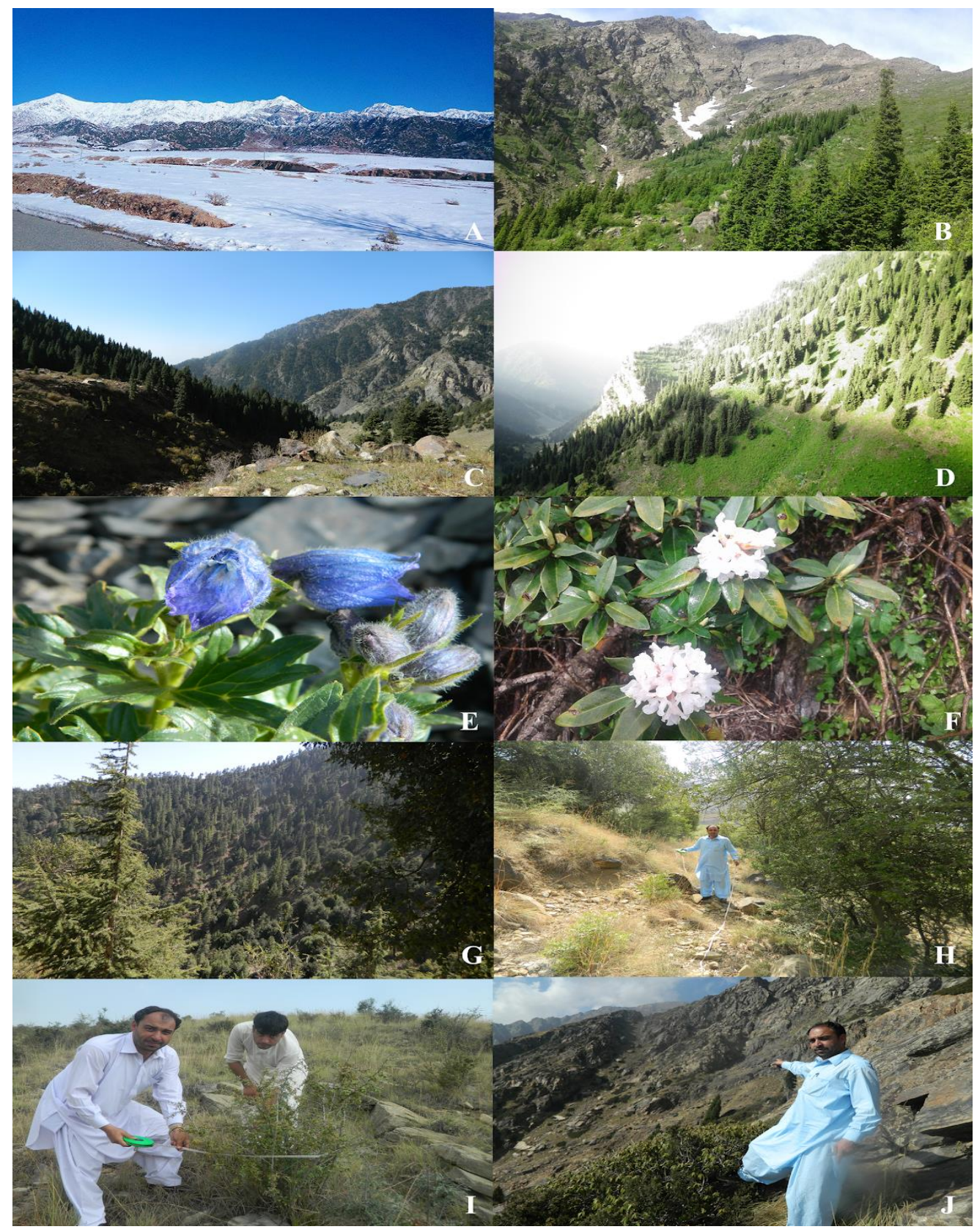

Figure 4. Pictorial view of the study area, (A) A beautiful view of Koh-e-Safaid Range, (B) Subalpine vegetation, $(C)$ North facing slopes of temperate site $(D)$ North facing slopes $(E)$

Delphinium brunonianum alpine plant in flowering stage $(F)$ Rhododendron afghanicum of subalpine plant in flowering stage $(G)$ Cedrus deodara forest $(H)$ Principal author in field at subtropical site at south facing slope (I) measuring canopy cover of Berberis lyceum (J) Principal author showing steep slopes of Alpine zone 
These findings are backed by works of Ali et al. (2018), Dad (2016), Ilyas et al. (2015), Siddiqui et al. (2015) and Ahmad et al. (2010). Cedrus-Quercus-Juniperus community was recorded at on the South Facing Slopes of Temperate Zone. The area had uniformly spread thin Cedrus deodara forest mixed with Quercus semicarpifolia and Juniperus excelsa. The area was under tremendous biotic stress especially cutting of Pinus gerardiana, Pinus wallichiana, Cedrus deodara for timber wood in past and completely missing of herbage cover due to steep slopes, lacking topsoil and allopathic effect of shading leaves of Cedrus, Pinus and Juniperus trees. This is line with findings of Ali et al. (2018), Ahmad et al. (2016), Khan et al. (2016), Akhtar and Bergmeier (2015), Shaheen et al. (2015), Sharma et al. (2014), Hussain et al. (2010) and Jabeen and Ahmad (2009). On the North Facing Slopes of Sub-Alpine Abies-Picea-Rhododendron community was recorded. The Rhododendron afghanicum was uniformly distributed on the open space of forest as well as inside the forest. Forest at this site was found in good health. Deforestation was also not that alarming as compared to that of other monitoring sites. Juniperus-Rheum-Kobresia community was recorded at alpine zone. This is treeless zone and only two shrubs were recorded first one was Juniper excelsa and the second was Rhododendron afghanicum and dominated by the herbs i.e. Kobresia schoenoides. This site shrub growth was stunted, and trees were scanty due to unfavorable conditions. These results are in line with the works of Ali et al. (2018), Khan et al. (2016, 2012), Haq et al. (2015), Sharma et al. (2014) and Ahmad et al. $(2010,2006)$. The soil texture of the research area was typically sandy loam and loamy sand, with $\mathrm{pH}$ ranged from 7.3 to 7.7 . Organic matter varied from 1.4 to $2.4 \%$ and electric conductivity from $0.6 \mathrm{dSm}^{-1}$ to $1.6 \mathrm{dSm}^{-1}$. The $\mathrm{CaCo}_{3}$ ranged from 2.6 to $7.8 \%$, $\mathrm{HCO}_{3}$ from 3.0 to $8.0 \%$ and sulphates from 0.4 to $7.8 \%$ respectively. Nitrogen concentration ranged from 0.280 to $0.569 \%$, phosphorus from 435 to $810 \mu \mathrm{g} / \mathrm{g}$, potassium from 1090 to $9900 \mu \mathrm{g} / \mathrm{g}$, calcium from 32100 to $39900 \mu \mathrm{g} / \mathrm{g}$, magnesium from 5100 to $6800 \mu \mathrm{g} / \mathrm{g}$ and sulphur from 163 to $263 \mu \mathrm{g} / \mathrm{g}$. The micro nutrients such as iron ranged from 15000 to $89200 \mu \mathrm{g} / \mathrm{g}$, manganese was enumerated as 343 to $976 \mu \mathrm{g} / \mathrm{g}$, copper was found to be 55 to $109 \mu \mathrm{g} / \mathrm{g}$ and zinc varied from 53 to $84 \mu \mathrm{g} / \mathrm{g}$, however, sodium was recorded from 1300 to $3300 \mu \mathrm{g} / \mathrm{g}$ and chlorine as 1500 to $3500 \mu \mathrm{g} / \mathrm{g}$.

\section{Conclusions}

This study reveals results of vegetation mapping based on 140 sampling units at 7 monitoring sites while results of soil analysis cover 18 parameters. Spatial variation among plant communities at different monitoring sites is attributed to variations in edaphic variables, climate and different ecological parameters. Anthropogenic activities, over grazing, natural disasters and erosion are reducing the vegetation cover. Extraction of fuel wood from forest, especially during harsh winters by the local people is alarming. Impacts of anthropogenic pressure are evident from low scores for maturity index (48.88) at Sub-Tropical Plain area. Low values for maturity index indicate inability of the plant communities to cope with anthropogenic, edaphic and climatic stresses. Similarly, low values for similarity index show the heterogeneity among the reported different 7 plant communities. However, cluster analysis using PAST software and PC-Ord software version 5, classified the vegetation into three groups and four groups based on quantitative value. Afforestation programs need to be started on wasteland of the area to overcome the impacts of deforestation. There is severe deforestation pressure on woody and shrubby species especially on Quercus baloot, 
Quercus semicarpifolia, Cedrus deodara, Abies pindrow, Pinus wallichiana, Indigofera gerardiana, Sophora mollis and Syringa afghanica. Therefore, alternate sources of fuel/timber should be provided, and the area must be protected to promote vegetation cover. Effective measures like afforestation and control of overgrazing are needed to avoid soil erosion.

Acknowledgements. This study is part of the Doctoral work of the principal author. This research did not receive any specific grant from funding agencies in the public, commercial, or not-for-profit sectors.

\section{REFERENCES}

[1] Ahmad, M., Husain, T., Sheikh, A. H., Hussain, S. S., Siddiqui, M. F. (2006): Phytosociology and structure of Himalayan forests from different climatic zones of Pakistan. - Pak. J. Bot. 38(2): 361-383.

[2] Ahmad, M., Shoukat, S. S., Khan, D. (2010): Status of vegetation analysis in Pakistan. Int. J. Biol. Biotech. 7(3): 147-158.

[3] Ahmad, K. S., Ahmad, M., Ahmad, F., Sadia, B. (2016): Edaphic factors as major determinants of plant distribution of temperate Himalayan grasses. - Pak. J. Bot. 48(2): 567-573.

[4] Akhtar, N., Bergmeier, E. (2015): Species richness, alpha and beta diversity of trees, shrubs and herbaceous plants in the woodlands of Swat, Pakistan. - Pak. J. Bot. 47(6): 2107-2113.

[5] Ali, S. M., Malik, R. N. (2010): Vegetation communities of urban open spaces: green belts and parks in Islamabad city. - Pak. J. Bot. 42(2): 1031-1039.

[6] Ali, S., Perveen, A., Qaiser, M. (2015): Vegetation structure and edaphology of Mahaban and Malka (District Buner) KPK, Pakistan. - Pak. J. Bot. 4(7): 15-22.

[7] Ali, A., Badshah, L., Hussain, F. (2018): Vegetation structure and threats to Montane Temperate ecosystems in Hindukush Range, Swat, Pakistan. - Applied ecology and environmental research. 16(4): 4789-4811.

[8] Badshah, L., Hussain, F., Akhtar, N. (2010): Vegetation structure of subtropical forest of Tabai, South Waziristan, Pakistan. - Front. Agric. China. 4(2): 232-236.

[9] Badshah, L., Farrukh, H., Zaman, S. (2016): Floristic inventory, ecological characteristics and biological spectrum of plants of Parachinar, Kurram Agency, Pakistan. - Pak. J. Bot. 48(4): 1547-1558.

[10] Bokhari, T. Z., Ahmed, M., Siddique, M. F., Khan, Z. (2013): Forest communities of Azad Kashmir, Pakistan. - FUUAST J. Biol. 3(1): 137.

[11] Bouyoucos, G. J. (1936): Directions for making mechanical analysis of soils by the hydrometer method. - Soil Sci. 42: 225-228.

[12] Brady, N. C. (1990): The Nature and Properties of Soils. 10th Ed. - Macmillan Publishing Co. New York.

[13] Bremner, J., Mulvaney, C. S. (1982): Nitrogen - Total. - In: Page, A. L. et al. (eds.) Methods of Soil Analysis Agronomy Monograph. 9, Part 2, 2nd Ed. American Society of Agronomy, Madison, WI. pp. 595-624.

[14] Dad, J. M. (2016): Distribution, species diversity and composition of plant communities in relation to various affecting factors in an Alpine grassland at Bandipora, Kashmir. Pak. J. Bot. 48(2): 551-560.

[15] Digiovinazzo, P., Ficetola, G. F., Bottoni, L., Andreis, C., Schioppa, E. P. (2010): Ecological thresholds in herb communities for the management of suburban fragmented forests. - Forest Ecology \& Management 259(3): 343-349.

[16] Forzieri, G., Castelli, F., Vivoni, E. R. (2011): Vegetation dynamics within the North American monsoon region. - J. Clim. 24(6): 1763-1783. 
[17] Haq, F., Ahmad, H., Iqbal, Z. (2015): Vegetation description and phytoclimatic gradients of subtropical forests of Nandiar Khuwar catchment District Battagram. - Pak. J. Bot. 47(4): 1399-1405.

[18] Hussain, A., Farooq, M. A., Ahmad, M., Akbar, M., Zafar, M. U. (2010): Phytosociology and structure of central Karakoram national park (CKNP) of Northern areas Pakistan. World App. Sci. J., 9(12): 1443-1449.

[19] Hussain, A., Adhikari, A., Iqbal, C. M., Ayatollahi, S. A., Rahman, A. (2016): New adduct of abietane-type diterpene from Salvia leriifolia Benth. - Nat. Prod. Res. 30(13): 1511-1516.

[20] Hussain, F., Shah, S. M., Badshah, L., Durrani, M. J. (2015): Diversity and ecological characteristics of flora of Mastuj Valley, District Chitral, Hindukush Range, Pakistan. Pak. J. Bot. 39(2): 339-354.

[21] Hussain, W., Hussain, J., Hussain, S., Shinwari, Z. K., Ali, R., Basir, A. (2013): Ethnomedicinal study of Parachinar, Kurram Valley (FATA) KPK, Pakistan. - JAPS. 3(11): 085-088.

[22] Hussain, W., Badshah, L., Shah, S. A., Hussain, F., Ali, A., Sultan, A. (2019): Salvia reflexa (Lamiaceae): a new record for Pakistan. - Plant Science Today. 6(1): 17-21.

[23] Ilyas, M., Qureshi, R., Akhtar, N., Haq, Z. (2015): Vegetation analysis of Kabal Valley, District Swat, Pakistan using multivariate approach. - Pak. J. Bot. 4(7): 77-86.

[24] Ilyas, M., Qureshi, R., Akhtar, N., Haq, Z. (2018): Vegetation structure of the remnant sub-tropical broad leaves forests from Kabal Valley, Swat, Pakistan. - Pak. J. Bot. 50(1): 217-230.

[25] Jabeen, T., Ahmad, S. S. (2009): Multivariate analysis of environmental and vegetation data of Ayub National Park, Rawalpindi. - Soil \& Env. 28(2): 106-112.

[26] Jackson, M. L. (1962): Soil Chemical Analysis. - Constable \& Co., Ltd., London, pp. 406-407.

[27] Khan, A., Ahmad, M., Siddiqui, M. F., Iqbal, J., Wahab, M. (2016): Phytosociological analysis of Pine forest at Indus Kohistan, KPK, Pakistan. - Pak. J. Bot. 48(2): 575-580.

[28] Khan, N., Ahmed, M., Siddiqui, M. F., Bibi, S., Ahmed, I. (2012): A phytosociological study of forest and non-forest vegetation of District Chitral, Hindukush Range, Pakistan. - FUUAST J. Bio. 2(1): 91-101.

[29] Kuma, M., Shibru, S. (2015): Floristic composition, vegetation structure, and regeneration status of woody plant species of Oda Forest of Humbo Carbon Project, Wolaita, Ethiopia. - J. Bot. Ethio. 15(01): 01-09.

[30] Mahmood, T., Andleeb, S., Anwar, M., Rais, M., Nadeem, M. S., Akrim, F., Hussain, R. (2015): Distribution, abundance and vegetation analysis of the scaly ant-eater (Manis crassicaudata) in Margalla Hills National Park Islamabad, Pakistan. - JAPS 25(5): 13111321.

[31] Mesdaghi, M. (2001): Vegetation Description and Analysis: A Practical Approach. 1st Ed. - Jehad Daneshgahi of Mashhad, Mashhad, p. 161-179.

[32] Mohler, C. L., Marks, P. L., Gardescu, S. (2006): Guide to the Plant Communities of Central Finger Lakes Region. - New York State Agricultural Experiment Station, New York, pp. 7-9.

[33] Motyka, J., Dobrzanski, B., Zawadski, S. (1950): Wstepne badania nad lakami polundnlowowschodneij Lubeiszczyzny. - Ann. Univ. M. Curie-Sklodowska 13: 367447.

[34] Munhoz, C. B. R., Felfili, J. M. (2006): Phytosociology of the herb-subshrub layer in an area of Campo Sujo, Distrito Federal, Brazil. - Acta Bot. Bras. 20(3). http://dx.doi.org/10.1590/S0102-33062006000300017.

[35] Padalia, H., Chauhan, N., Porwal, M. C., Roy, P. S. (2004): Phytosociological observations on tree species diversity of Andaman Islands, India. - Current Sci. 87: 799806. 
[36] Pichi-Sermolli, R. E. (1948): An index for establishing the degree of maturity in plant communities. - J. Ecol. 36: 85-90.

[37] Rajendran, S., Al-Sayigh, A. R., Al-Awadhi, T. (2016): Vegetation analysis study in and around Sultan Qaboos University, Oman, using Geoeye-1 satellite data. - EJRS. 19(2): 297-311.

[38] Rashid, A., Swati, M. F., Sher, H., Al- Yemeni, M. N. (2011): Phytoecological evaluation with detail floristic appraisal of the vegetation around Malam Jabba, Swat, Pakistan. Asian Pac. J. Trop. Biomed, 2(11): 461-467.

[39] Rhoades, J. D. (1996): Salinity: Electrical Conductivity and Total Dissolved Solids. - In: Sparks D. L. (ed.) Methods of Soil Analysis: Chemical Methods, Part 3. ASA and SSSA, Madison, WI, pp. 417-435.

[40] Richard, L. A. (1954): Diagnoses and Improvement of Saline and Alkali Soils. Agriculture Hand Book, 60: USDA, USA.

[41] Ryan, J., George, E., Rashid, A. (1997): Soil and Plant Analysis Laboratory Manual. 2nd Ed. - ICARDA, Aleppo, pp: 7-8.

[42] Saglam, C. (2013): A phytosociological study of the forest, shrub, and steppe vegetation of Kizildag and environs (Isparta, Turkey). - Turk. J. Bot. 37: 316-335.

[43] Salehi, A., Zarinkafsh M., Zahedi G. H., Marvi M. R. (2005): A study of soil physical and chemical properties in relation tree ecological groups in Nam-Khaneh district of KheirodKenar forest. - Iran. J. Nat. Res., 5(8): 567-577.

[44] Saurav, M., Das, A. P. (2014): Plant species richness and phytosociological attributes of the vegetation in the cold temperate zone of Darjilling Himalaya, India. - Int. Res. J. Env. Sci. 3(10): 47-57.

[45] Shaheen, H., Sarwar, R., Firdous, S. S., Dar, M. E. I., Zahidullah., Khan, S. M. (2015): Distribution and structure of conifers with special emphasis on Taxus baccata in moist temperate forests of Kashmir Himalayas. - Pak. J. Bot. 47(SI): 71-76.

[46] Sharma, P., Rana, J. C., Devi, U., Randhawa, S. S., Kumar, R. (2014): Floristic diversity and distribution pattern of plant communities along altitudinal gradient in Sangla valley, Northwest Himalaya. - The Sci. World. J. http://dx.doi.org/10.1155/2014/264878.

[47] Sher, Z., Farrukh, H., Badshah, L. (2014): Biodiversity and ecological characterization of the flora of Gadoon Rangeland, District Swabi, Khyber Pukhtunkhwa, Pakistan. - Iran J. Bot. 20(01): 96-108.

[48] Siddiqui, M. F., Ahmed, M., Shaukat, S. S., Khan, N. (2010): Advance multivariate techniques to investigate vegetation-environmental complex of pine forests of moist area of Pakistan. - Pak. J. Bot. 42: 267-293.

[49] Siddiqui, M. F., Salam, A., Ahmad, M., Hussain, M. I., Iqbal, J., Wahab, M. (2015): Present state and future trends of pine forests of Malam Jabba, Swat District, Pakistan. Pak. J. Bot. 47(6): 2161-2169.

[50] Sorensen, T. (1948): A method of establishing groups of equal amplitudes in plant sociology based on similarity of species content and its application to analyze the vegetation of Darnish commons. - Biol. Skr. 5: 1-34.

[51] Taleshi, H. (2004): Phytosociology of lowland forests in eastern Nowshahr (North of Iran). - M.Sc. Thesis, Tarbiat Modares University (in Persian).

[52] Timilehin, K. E., Olajide, O. S., Ademayowa, O., Olusanya, O. (2017): Floristic composition and structural diversity of Ibodi Monkey Forest, Ibodi, Southwestern Nigeria. - Pak. J. Bot. 49(4): 1359-1371.

[53] Urooj, R., Ahmad, S. S., Ahmad, M. N., Ahmad, H., Nawaz, M. (2016): Ordination study of vegetation analysis around wetland area: a case study of Mangla Dam, Azad Kashmir, Pakistan. - Pak. J. Bot. 48(1): 115-119.

[54] Wahab, M., Ahmad, M., Khan, N., Sarangzai, A. M. (2010): A phytosociological study of pine forest from District Dir, Pakistan. - J. Biol. Biotech. 7(3): 219-226.

[55] Zoq-ul-Arfeen, R., Saleem, A., Mirza, S. N., Akmal, M., Tayyab, H. M., Afzal, O. (2015): Biodiversity and phytosociological studies of upstream and downstream 
riparianareas of Pakistan: Special reference to Taunsa Wildlife Sanctuary and Keti Shah Forests. - Pak. J. Agri. Sci. 28(4): 112-121.

[56] Zhu, H., Yong, S., Zhou, H., Wang, C., Yan, L. (2015): Vegetation, floristic composition and species diversity in a tropical mountain nature reserve in southern Yunnan, SW China, with implications for conservation. - Trop. Conserv. Sci. 8(2): 528-546. 